\section{Human Ecological Ethic?}

For such an integrating form of ethic ${ }^{1}$, there are certain encouraging signs and processes in which the strictly egoistical striving for advantage has given place to a more humanistic ethic: as, for instance, in the freeing of the slaves, the establishing of a world postal service for the general good, the declaration of human rights on the high seas, the international banking system, the world-wide publication of scientific advances, the international co-operation in the prevention of crime. There has even been some voluntary limitation of war-fare through the international Red Cross, the Geneva and Hague conventions.

There are now also several European and world organizations in recognition of the need for co-existence, and numerous international and national ecological congresses to initiate a wider co-operation - often enough without much concrete result ${ }^{2}$.

On the other side, there are the continuing international and national civil wars of the opposing political systems. And finally the ever-increasing, ruthless exploitation of nature, and the irresponsible manipulation of life which is destroying the natural control of the processes of evolution and selection. The artificial evolution caused by technical progress and the no less artificial selection through economic competition have become the most fatal threat to human existence.

All this is emphasized and discussed in detail in the descriptions of the human ecological crisis in which we live ${ }^{3}$. It is gradually becoming realized that this human ecological crisis has grown into a nihilistic crisis with a relativistic, pluralistic, sceptical and ideological abdication of all human values and cultural ideals.

A new age must be born: something of the order of a 'cybernetic age' is envisaged, with a new dimension of thought ${ }^{4}$. But from a mere material and intellectual process alone, no humanly satisfying future in a new age can be imagined; there must be a vehement general offensive of the combined forces of the widest concepts and efforts.

At first we are gathering the fruits of a particularized and political ethic. For the integral ethic which is forced upon us, we need all public bodies to arouse as much moral initiative as possible in individuals, and to collect and realise such initiatives. But these must, from the start, be ordered for all mankind, without ethical soverenity for certain communities or groupings. Such a human ecological ethic calls for individual inspiration, collective execution and universal acceptance. What is needed is the concrete achievement of the complex requirements of a true human ecology, whereby a sincere individual and collective ethic is essential. Such an integrating ethic must bind the universal orders to concrete codes of behaviour and achievement, and to the individual will to honesty, decency and justice.

With other words: What is needed is the exertion of a higher dimension of man which will not simply ignore discords but will tackle every discord. So an ethical integration could be made, and a forum for the productive

\section{OECOLOGICA HUMANA}

realization of ethical action and order in the whole world could be created.

But all appeals for a new ethic are powerless against the inevitability of the laws of socio-economic ecological processes. Man needs the clash with his own limitations: he needs the compulsion of necessity and the insight of higher reason, which is a self-knowledge produced by experience of the whole environment: higher reason since it must recognise the indivisibility of the world, and thus the right relationship of the inner world to the outer world. In terms of human ecology, a new socio-economic ecological equilibrium is called for ${ }^{5}$.

However, strict general ethical orders always lead to dilemma. To master such situations in which the participants are in a dilemma between different alternatives of equal value, requires, so to speak, 'a human ecological conscience', an inner 'compass of behaviour'. In the conflict between the present and future generations, it cannot be a question of sacrificing the one or the other, either individuals or a whole generation. A true conflict can only be between 'wellbeing' and 'survival' of the one or other generation. Well-being cannot be understood as the retention of the present status quo, ignoring the possibilities of development and the will to develop. ${ }^{6}$ The precedence of statistical values over developmental values cannot be tolerated. A human ecological ethic must be demanded which would integrate the outer environment and also the relationship between humans and the inner world of human beings. Here the balance between the objective and the subjective in the ethic is of dominant importance, since it is the problem of the whole of mankind and of human society as a unity.

We have attempted hereby merely to set forward a few thoughts and possibilities of human ecological ethics to stimulate further discussion in Experientia. The alternatives which face mankind never remain in the abstract sphere. Decisions to be taken can also never be made purely on ethical grounds. Man in all his plannings and actions has always to start from quite concrete situations, whereby the level of technical possibility is part-determinant. It is on the basis of our knowledge of the vital essentials and the socioeconomic-ecological conditions that the ethical demands and the practical technical possibilities have to be brought in harmony with each other.

H. MisLin

1 H. Mislin, Towards a Human Ecology and Biopolitic; Experientia 25,224 (1969).

2 K. E. SChaEfer, The Environmental Crisis. Commentary on the 1970 European Conservation Year; Experientia 26, 672 (1970).

3 V. LAbeyrie, Modèles écologiques et aménagement de l'espace; Experientia 28, 616 (1972).

4 F. VEster, Das kybernetische Zeitalter (Fischer Verlag, Frankfurt a.M. 1974).

5 P. A. Tschumr, Will the Exploding Human Population Succeed in Conserving Nature? Experientia 26, 572 (1970).

6 P. Beaconsfield, R. Rainsbury, J. Huxley, R. Peters, J. Tréfouel, J. Monod, R. Paul, H. Theoreld, Suggestion for a Study of Various Chemicals and Non-Disease Specific Drugs; Experientia 27,715 (1971). 